\title{
Effects of stand density on soil respiration and labile organic carbon in different aged Larix principis-rupprechtii plantations
}

Tairui Liu', Daoli Peng ${ }^{1 *}$, Zhijie Tan², Jinping Guo $^{3}$ and Yunxiang Zhang ${ }^{3}$

\begin{abstract}
Background: The carbon pools of forest soils play a vital role in global carbon sequestration and emissions. Forest management can regulate the sequestration and output of forest soil carbon pools to a certain extent; however, the kinetics of the effects of forest density on soil carbon pools require further investigation.

Methods: We established sample plots with stand density gradients in three different aged Larix principis-rupprechtii plantations and quantified the soil respiration, soil organic carbon (SOC), soil dissolved organic carbon (DOC), microbial biomass carbon (MBC), light fraction organic carbon (LFOC), and readily oxidized carbon (ROC).

Results and conclusions: During the growth and development of plantations, stand density is an essential factor that impacts soil respiration and its associated elements. Moderate density was observed to promote both the soil and heterotrophic respiration rates and the sequestration of $\mathrm{MBC}$ and LFOC, whereas it inhibited the sequestration of ROC. The soil, heterotrophic, and autotrophic respiration rates of older forest stands were relatively rapid, whereas the contents of SOC, MBC, LFOC, DOC, and ROC were higher and more sensitive to changes in stand density. The MBC, LFOC, and ROC in soil labile organic carbon were closely related to both the soil and heterotrophic respiration, but not the SOC. Among them, the LFOC and MBC played the roles of "warehouse" and "tool" and were significantly correlated with soil and heterotrophic respiration. The ROC, as a "raw material", exhibited a significantly negative correlation with the soil and heterotrophic respiration. When the soil and heterotrophic respiration rates were rapid, the ROC content in the soil maintained the low level of a "dynamically stabilized" state. The stand density regulated heterotrophic respiration by affecting the soil labile organic carbon, which provided an essential path for the stand density to regulate soil respiration.
\end{abstract}

Keywords: Stand density, Soil respiration, Soil organic carbon, Soil labile organic carbon, Influence mechanism

\section{Introduction}

Forests comprise the world's largest ecosystems, which contain tremendous quantities of carbon that are sequestered by plants (Poorter et al. 2016; Khan et al. 2018; Franklin et al. 2009). The soil carbon pool, which is the second largest, after the ocean, on a global scale cannot be ignored (Lal 2005; Sedjo 1993). The continuous carbon exchange between soil and atmosphere

\footnotetext{
* Correspondence: dlpeng@bjfu.edu.cn

'College of Forestry, Beijing Forestry University, No. 35 Tsinghua East Road, Haidian District, Beijing 100083, People's Republic of China

Full list of author information is available at the end of the article
}

significantly impacts the global carbon cycle and climate change (Dib et al. 2014; Gabriel et al. 2018; Tian et al. 2016). Though forest soils store the largest share of carbon in various forms (Jílková 2020; Tian et al. 2016), it exchanges carbon with the ambient atmosphere via decomposition, i.e., soil respiration (Wei et al. 2010; Goldberg et al. 2017). Thus, elucidating the characteristics of forest soil respiration and carbon sequestration is critical for the management of forest ecosystems. Through the proper management of forests, the processes of greenhouse gas emissions and soil organic carbon sequestration may be controlled to a certain extent.

\section{Springer Open}

(- The Author(s). 2021 Open Access This article is licensed under a Creative Commons Attribution 4.0 International License, which permits use, sharing, adaptation, distribution and reproduction in any medium or format, as long as you give appropriate credit to the original author(s) and the source, provide a link to the Creative Commons licence, and indicate if changes were made. The images or other third party material in this article are included in the article's Creative Commons licence, unless indicated otherwise in a credit line to the material. If material is not included in the article's Creative Commons licence and your intended use is not permitted by statutory regulation or exceeds the permitted use, you will need to obtain permission directly from the copyright holder. To view a copy of this licence, visit http://creativecommons.org/licenses/by/4.0/. 
Stand density, which is typically regulated by thinning, is considered to have an indispensable influence on forest production. The principle of thinning may form the localized climax of plant communities as the basis of forest management research (Ming et al. 2018; Jens et al. 2000), which may also be based on the integrity principle of forest ecosystems. Therefore, the effects of stand density are limited not only through the modification of canopies and vertical forest structures (Jack and Long 1991; Liu et al., 2019, b), but also microclimates, interspecific competition, and more (Ali et al. 2019; Eldegard et al. 2019; Bello et al. 2019; Shao and Shugart 1997; Liu et al., 2019, b).

In previous studies, it was considered that soil respiration (Rs) involves autotrophic respiration $(\mathrm{Ra})$ and heterotrophic respiration ( $\mathrm{Rh})$, whereby the decomposition of microorganisms and turnover of roots in the soil are the main forms of heterotrophic and autotrophic respiration, respectively (Baggs 2006; Xu and Shang 2016; Hopkins et al. 2013). This process provides a better understanding of the soil respiration mechanism and the various factors that influence it. These studies were conducted on forest soils within 2 years of the thinning of a Carpinus betulus plantation. Significantly higher soil microbial respiration was reported for the thinned plots in contrast to the controls, whereas no significant differences in soil respiration were reported between three thinning intensities (Akburak and Makineci 2016).

In a study of mature Masson pine forests, Lei et al. (2018) reported that stand thinning could effectively increase the rate of soil respiration over a short period of time. When studying the soil respiration of young Pinus tabulaeformis forests, it was reported that moderate thinning positively impacted soil respiration by altering the soil temperature and humidity (Cheng et al. 2015), with similar results being reported elsewhere (Zhang et al. 2018). Numerous researchers found that moderate thinning could alter the microclimates of stands, thereby optimizing the living conditions for soil microorganisms, while reserving sufficient soil substrates and soil organic carbon for respiration. However, several researchers reported different results, including that thinning might cause the death of plant roots and reduce autotrophic soil respiration, where much sparser stands would decrease the activities of soil microorganisms (Mosca et al. 2017; Park et al. 2009).

Soil organic carbon (SOC) comprises $\mathrm{C}$ that is contained in soil organic matter (SOM), which is an important indicator for the quantification of soil carbon sequestration (Lull et al. 2020), and is strongly affected by land-use changes, forest management, natural and anthropogenic interference, and other factors. The levels of organic carbon in forest soils are attributed to dynamic and robust changes (Cambardella and Elliott 1992; Liang et al. 1997). However, due to the complexity of the composition and structure of the soil, as well as the existence of soil organic matter, the performance of certain functional characteristics is often the result of the simultaneous action of a chemical mixture with similar chemical elements, structural characteristics, and functional groups.

It is not only the total amount of soil organic carbon and its degree of activity that characterizes soil carbon pool activities, but also labile soil organic carbon. The active component of soil organic carbon is the most dynamic and unstable $C$ in the soil, which has the characteristics of availability, easy oxidation, and solubility. Generally, soil carbon may be categorized based on the stability of SOC and measure of dissolved organic carbon (DOC) in the soil, including microbial biomass carbon $(\mathrm{MBC})$, light fraction organic carbon (LFOC), and readily oxidized carbon (ROC). This is considered as the most quantitative expression of soil labile organic carbon (Hu et al. 2010).

It has been reported that decreased stand density increases soil temperature, humidity, soil respiration, soil SOC, N, P, K, etc. (Zhang et al. 2018; Wic Baena et al. 2013). However, many studies have found that changes in soil temperature, humidity, and soil respiration via thinning might become stable following a certain time period and even return to original levels (Olajuyigbe et al. 2012; Bai et al. 2016; Fernandez et al. 2012). These studies also conveyed that the root systems or plants remaining in the stand subsequent to thinning served as exogenous carbon, which translated to changes in the soil rather than being the effect of stand density. Most existing research has focused on the short-term "stress response" of forest soil carbon pools following thinning (Zhao et al. 2019; Ryu et al. 2009; Bolat 2013).

Although thinning directly alters stand density, its impact on the soil should be the steady state achieved by biochemical action under the influence of different stand densities. The effects of stand density on the soil carbon pool are initiated through the interactions of litter return, root growth and respiration, microbial activity, and mineral turnover subsequent to thinning. Our study aimed to focus more on the effects of different stand densities on soil respiration and soil labile organic carbon and their kinetics.

It is not clear whether the soil carbon pools of different aged plantations have variable responses to different stand densities. This study focused on forest development and growth to guide more effective anthropogenic interventions and forest management practices in forests across all ages. As the substrate of soil respiration, soil organic carbon cannot be discussed in isolation. The hypothesis proposed for this study is that both stand density and age are essential factors that influence soil 
respiration, soil organic $\mathrm{C}$, and soil labile organic $\mathrm{C}$, with a close correlation between soil labile organic $\mathrm{C}$ and respiration. Consequently, the objectives of this study were to (1) examine whether Rs, Rh, Ra, SOC, MBC, DOC, LFOC, and ROC in mineral soil would be significantly affected by stand density and stand age during the study period (5 years after thinning); identify the variable trends mentioned above with stand density; and compare the trends for different stand ages and (2) identify the critical factors that shape the Rs, Rh, and Ra in soil organic carbon pools.

\section{Materials and methods \\ Study area}

The study area is located in Yeshagou $\left(37^{\circ} 44^{\prime} \mathrm{N}, 111^{\circ}\right.$ $30^{\prime}$ E) at the Xiaowenshan Forest Farm of the Pangquangou Nature Reserve, Lüliang city, Shanxi Province, China, with an altitude of 1760-2210 m (Fig. 1). The climate of this area is temperate continental monsoon, with cold dry winters and hot humid summers. The annual average temperature is $4.2^{\circ} \mathrm{C}$, precipitation is 822.6 $\mathrm{mm}$, and relative humidity is $70.9 \%$. The soil type is leached cinnamon with a humus layer thickness of 3-7 cm. In the study area, the forest types are primarily pure Larix principis-rupprechtii and Pinus tabulaeformis plantations, which are occasionally accompanied by Betula platyphylla and Quercus liaotungensis. The main shrub species are Spiraea saliifolia, Rosa xanthina, and Lespedeza bicolor.

Toward the end of April 2020, we selected subcompartments that had similar site conditions, slopes, and slope positions of different ages, with an area of more than 2 ha, according to the average height of the dominant trees (Larix principis-rupprechtii); the ages of the sub-compartments were 27 (27a), 36 (36a), and 48 years old (48a). To prevent anthropogenic interference and short-term effects after thinning, the latest thinning operation was conducted in the sub-compartment in 2015 , with a subsequent thinning of the same area in 2020. Based on the differences in stand density formed by thinning, nine standard sample plots $(20 \mathrm{~m} \times 20 \mathrm{~m})$ with different stand densities were demarcated in the stands of different ages (stand density was calculated according to the actual density on the sample plot), and a 5-m-wide buffer zone was established around the sample plots. A total of 27 sample plots were established with inter-plot distances limited to $40 \mathrm{~m}$. We set three sample plots with similar stand densities as replicates and divided the nine sample plots of each age group into three density levels, namely high density (HD), medium density (MD), and low density (LD). We measured the trees with a $\mathrm{DBH}$ greater than $5 \mathrm{~cm}$ in each plot and recorded their DBH, height, and other parameters.

\section{Field survey and soil sampling}

When establishing the sample plots, we randomly installed six polyvinyl chloride (PVC) rings with inner diameters of $20 \mathrm{~cm}$ and heights of $10 \mathrm{~cm}$ and drove them into the soil by $\sim 6 \mathrm{~cm}$ with a hammer. Three of these rings were treated with root removal, via the trench method, to distinguish autotrophic respiration from heterotrophic respiration. The root removal method

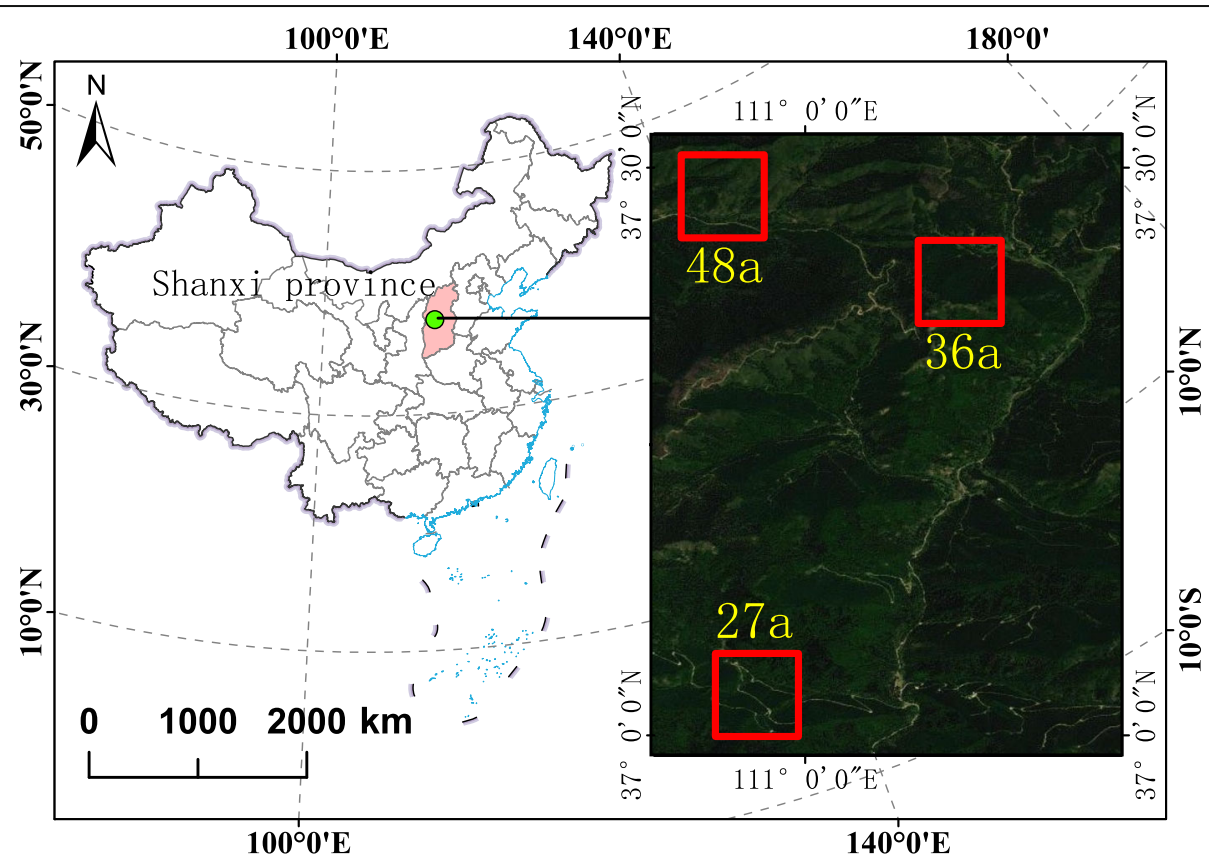

Fig. 1 Study area. (27a) 27-year-old stand. (36a) 36-year-old stand. (48a) 48-year-old stand 
involved the selection of a $0.5 \mathrm{~m} \times 0.5 \mathrm{~m}$ area and digging vertical trenches to a depth of $0.6-0.8 \mathrm{~m}$ around this area with a shovel (to the depth of the root system accessed), cutting off the roots (but not removing them) and inserting a 100-mesh nylon net to prevent root growth (Kuzyakov 2006). The vegetation of the sample plot was clipped, and all of the trench-digging sample plots were regularly cleared of surface vegetation and litter to clearly distinguish between autotrophic and heterotrophic respiration.

To avoid the influences of soil disturbances, soil respiration was measured twice in mid-July 2020. A soil carbon flux automatic measurement system (Li 8100a, Li-COR, Inc., Lincoln, NE) was applied to measure the soil respiration three times for each respiratory ring. The measurements were made between 9:00 am to 15:00 pm, and the soil respiration in stands of the same age with different densities was also measured during the same period. A total of 972 measurements for 162 respiratory rings were made. The soil was sampled at depths of 0 $10 \mathrm{~cm}, 10-20 \mathrm{~cm}$, and $20-30 \mathrm{~cm}$ using a $\varnothing 5-\mathrm{cm}$ circular soil auger.

Three samples from each soil layer were collected for a total of nine soil samples per sample plot and 243 soil samples overall. The collected soil samples were placed within numbered aseptic soil bags, stored at low temperature, and transferred to the laboratory. Fine roots and stones were removed from the soil samples, which were then sifted through 2-mm holes, and divided into two parts. One sample was fresh and stored in a $4^{\circ} \mathrm{C}$ refrigerator to determine the $\mathrm{MBC}$ and $\mathrm{DOC}$, whereas other collected soil samples were dried in the laboratory to determine their physical and chemical properties and other labile organic carbon components (SOC, ROC, and LFOC). A summary of the characteristics of the sample plots is presented in Table 1.

\section{Soil sample analysis}

The physical and chemical properties of the soil samples, including the moisture content, bulk density, and $\mathrm{pH}$, were quantified. The TN was measured using the Kjeldahl method, whereas the TP was measured via the sulfuric acid digestion-colorimetric technique (Qiu et al. 2019).

The SOC was measured using the potassium permanganate external heating method, and the ROC was measured via the potassium permanganate oxidation colorimetric method. Further, the soil dissolved organic carbon and soil microbial carbon were measured through chloroform fumigation and the $\mathrm{K}_{2} \mathrm{SO}_{4}$ extraction methods, respectively. Subsequently, a multi-N/C 2100 (Jena) was employed to measure the TOC/TN, whereas the LFOC was separated via a NAI solution with a specific gravity of $1.7 \mathrm{~kg} / \mathrm{L}$ and measured via the potassium permanganate external heating method $\mathrm{CHu}$ et al. 2010).

\section{Data processing}

We calculated the Ra as follows:

$$
R a=R s-R h
$$

where Ra refers to autotrophic respiration, Rs refers to soil respiration, and $\mathrm{Rh}$ refers to heterotrophic respiration (obtained by the trench method).

We calculated the MBC as follows:

$$
M B C=\left(C_{u}-C_{u f}\right) / K
$$

where $C_{\mathrm{u}}$ is the carbon content of the fumigated soil extract, and $K$ is the conversion coefficient of the fumigated extraction method (0.45) (Brookes et al. 1985).

Based on the testing normality and consistency of the data, statistical analysis was performed with multi-factor analysis of variance, linear and quadratic regressions, structural equation modeling, correlation analysis, and redundancy analysis using R4.0.3 ( $\mathrm{R}$ Development Core Group), with all of the illustrations for this article being created using this software version.

\section{Results}

Factors affecting SOC, soil labile organic carbon, and soil respiration

We employed a multi-factor analysis of variance to test the factors that may affect the Rs, SOC, and labile organic carbon. The stand density significantly influenced the Rs, $\mathrm{Rh}$, and $\mathrm{Ra}$ (Table 2), whereas the stand age had no significant impacts on the soil respiration or its components, and the interactions between stand density and age had no significant effect. The SOC and labile organic carbon were significantly impacted by both the stand density and age. Except for the DOC and LFOC, other organic carbon measures were not very sensitive to the interactive effects of stand density and age, which meant that the regulating effects of stand density on soil respiration were significant. Further, the sequestration state of the SOC and labile organic carbon components were significantly affected by stand density and age.

\section{Effects of stand density on soil respiration}

We analyzed the differences between the Rs, Rh, and $\mathrm{Ra}$ at different density levels and employed the advantages of density sequence diagrams to discover the trends of these indicators with stand density. Subsequently, we attempted to identify those mechanisms of stand density that influenced soil respiration. 
Table 1 Summary of the characteristics of the sample plots. [N40 $\mathrm{E}],\left[\mathrm{N} 10^{\circ} \mathrm{E}\right]$, and $\left[\mathrm{N} 20^{\circ} \mathrm{E}\right]$ where $\mathrm{N}$ is the reference direction, and $40^{\circ} \mathrm{E}$ is the deviation from the reference direction heading east. SWC, soil moisture content; BD, soil bulk density; TN, soil total nitrogen content; TP, soil total phosphorus content; $\mathrm{DBH}$, diameter at breast height; $\mathrm{pH}$, hydrogen ion concentration. Values are the mean \pm standard deviation (SD). Different lowercase letters $(a, b$, and $c)$ indicate significant differences $(P<0.05)$ between different stand density levels. 27a, 27-year-old stand; 36a, 36-year-old stand; 48a, 48-year-old stand

\begin{tabular}{|c|c|c|c|c|c|c|c|c|c|c|c|c|}
\hline $\begin{array}{l}\text { Stand } \\
\text { age }\end{array}$ & Aspect & $\begin{array}{l}\text { Stand density } \\
\text { (trees/ha) }\end{array}$ & $\begin{array}{l}\text { Elevation } \\
\text { (m) }\end{array}$ & $\begin{array}{l}\text { Slope } \\
\left({ }^{\circ}\right)\end{array}$ & $\begin{array}{l}\text { DBH } \\
(\mathrm{cm})\end{array}$ & $\begin{array}{l}\text { Height } \\
\text { (m) }\end{array}$ & $\begin{array}{l}\text { Stand density } \\
\text { level }\end{array}$ & SWC (\%) & $\begin{array}{l}\mathrm{BD}(\mathrm{g} / \\
\left.\mathrm{cm}^{3}\right)\end{array}$ & $\mathrm{pH}$ & $\begin{array}{l}\mathrm{TN}(\mathrm{g} / \\
\mathrm{kg})\end{array}$ & $\begin{array}{l}\mathrm{TP}(\mathrm{g} / \\
\mathrm{kg})\end{array}$ \\
\hline \multirow[t]{9}{*}{$27 a$} & {$\left[\mathrm{~N} 10^{\circ} \mathrm{E}\right]$} & 975 & 1854 & 13 & $\begin{array}{l}18.79 \pm \\
3.09\end{array}$ & $\begin{array}{l}14.38 \pm \\
1.45\end{array}$ & LD & $\begin{array}{l}39.62 \pm \\
3.03 a\end{array}$ & $\begin{array}{l}1.03 \pm \\
0.02 \mathrm{a}\end{array}$ & $\begin{array}{l}6.99 \pm \\
0.13 a\end{array}$ & $\begin{array}{l}2.23 \pm \\
0.21 a\end{array}$ & $\begin{array}{l}0.78 \pm \\
0.01 a\end{array}$ \\
\hline & & 1100 & 1860 & 14 & $\begin{array}{l}18.16 \pm \\
2.86\end{array}$ & $\begin{array}{l}14.43 \pm \\
1.32\end{array}$ & & & & & & \\
\hline & & 1250 & 1865 & 12 & $\begin{array}{l}18.23 \pm \\
2.10\end{array}$ & $\begin{array}{l}13.69 \pm \\
1.09\end{array}$ & & & & & & \\
\hline & & 1500 & 1860 & 12 & $\begin{array}{l}18.09 \pm \\
2.05\end{array}$ & $\begin{array}{l}14.77 \pm \\
0.87\end{array}$ & $\mathrm{MD}$ & $\begin{array}{l}40.17 \pm \\
1.64 a\end{array}$ & $\begin{array}{l}1.02 \pm \\
0.02 \mathrm{a}\end{array}$ & $\begin{array}{l}7.13 \pm \\
0.15 a\end{array}$ & $\begin{array}{l}2.40 \pm \\
0.11 b\end{array}$ & $\begin{array}{l}0.82 \pm \\
0.06 a\end{array}$ \\
\hline & & 1675 & 1864 & 11 & $\begin{array}{l}17.86 \pm \\
2.36\end{array}$ & $\begin{array}{l}13.73 \pm \\
1.99\end{array}$ & & & & & & \\
\hline & & 1825 & 1870 & 12 & $\begin{array}{l}18.01 \pm \\
3.10\end{array}$ & $\begin{array}{l}14.24 \pm \\
1.84\end{array}$ & & & & & & \\
\hline & & 2125 & 1868 & 10 & $\begin{array}{l}17.15 \pm \\
2.21\end{array}$ & $\begin{array}{l}13.85 \pm \\
2.01\end{array}$ & $\mathrm{HD}$ & $\begin{array}{l}34.46 \pm \\
2.57 \mathrm{~b}\end{array}$ & $\begin{array}{l}1.08 \pm \\
0.07 a\end{array}$ & $\begin{array}{l}7.05 \pm \\
0.09 a\end{array}$ & $\begin{array}{l}2.22 \pm \\
0.04 a\end{array}$ & $\begin{array}{l}0.77 \pm \\
0.01 a\end{array}$ \\
\hline & & 2300 & 1880 & 18 & $\begin{array}{l}15.87 \pm \\
2.77\end{array}$ & $\begin{array}{l}13.44 \pm \\
1.38\end{array}$ & & & & & & \\
\hline & & 2425 & 1885 & 14 & $\begin{array}{l}16.26 \pm \\
2.03\end{array}$ & $\begin{array}{l}14.04 \pm \\
3.32\end{array}$ & & & & & & \\
\hline \multirow[t]{9}{*}{$36 a$} & {$\left[\mathrm{~N} 40^{\circ} \mathrm{E}\right]$} & 525 & 2030 & 18 & $\begin{array}{l}24.60 \pm \\
3.65\end{array}$ & $\begin{array}{l}17.15 \pm \\
2.13\end{array}$ & LD & $\begin{array}{l}34.68 \pm \\
4.42 a\end{array}$ & $\begin{array}{l}1.12 \pm \\
0.04 a\end{array}$ & $\begin{array}{l}6.92 \pm \\
0.07 a\end{array}$ & $\begin{array}{l}3.05 \pm \\
0.37 a\end{array}$ & $\begin{array}{l}0.87 \pm \\
0.02 a\end{array}$ \\
\hline & & 750 & 2050 & 13 & $\begin{array}{l}22.57 \pm \\
2.56\end{array}$ & $\begin{array}{l}16.93 \pm \\
1.34\end{array}$ & & & & & & \\
\hline & & 925 & 2054 & 20 & $\begin{array}{l}21.92 \pm \\
3.14\end{array}$ & $\begin{array}{l}16.62 \pm \\
1.66\end{array}$ & & & & & & \\
\hline & & 1100 & 2043 & 15 & $\begin{array}{l}20.41 \pm \\
2.42\end{array}$ & $\begin{array}{l}15.98 \pm \\
2.07\end{array}$ & $\mathrm{MD}$ & $\begin{array}{l}31.74 \pm \\
7.59 \mathrm{ab}\end{array}$ & $\begin{array}{l}1.08 \pm \\
0.04 a\end{array}$ & $\begin{array}{l}7.1 \pm \\
0.13 a\end{array}$ & $\begin{array}{l}3.75 \pm \\
0.70 b\end{array}$ & $\begin{array}{l}0.92 \pm \\
0.03 a\end{array}$ \\
\hline & & 1325 & 2052 & 12 & $\begin{array}{l}19.96 \pm \\
3.77\end{array}$ & $\begin{array}{l}16.49 \pm \\
1.83\end{array}$ & & & & & & \\
\hline & & 1500 & 2063 & 15 & $\begin{array}{l}20.89 \pm \\
2.75\end{array}$ & $\begin{array}{l}16.03 \pm \\
1.98\end{array}$ & & & & & & \\
\hline & & 1550 & 2073 & 16 & $\begin{array}{l}19.71 \pm \\
3.01\end{array}$ & $\begin{array}{l}15.76 \pm \\
2.61\end{array}$ & $\mathrm{HD}$ & $\begin{array}{l}28.84 \pm \\
3.49 b\end{array}$ & $\begin{array}{l}1.07 \pm \\
0.05 a\end{array}$ & $\begin{array}{l}6.91 \pm \\
0.13 a\end{array}$ & $\begin{array}{l}3.42 \pm \\
0.17 a b\end{array}$ & $\begin{array}{l}0.85 \pm \\
0.06 a\end{array}$ \\
\hline & & 1700 & 2066 & 16 & $\begin{array}{l}18.12 \pm \\
3.16\end{array}$ & $\begin{array}{l}16.08 \pm \\
2.15\end{array}$ & & & & & & \\
\hline & & 2075 & 2070 & 17 & $\begin{array}{l}18.37 \pm \\
2.98\end{array}$ & $\begin{array}{l}16.36 \pm \\
1.97\end{array}$ & & & & & & \\
\hline \multirow[t]{7}{*}{$48 a$} & {$\left[\mathrm{~N} 20^{\circ} \mathrm{E}\right]$} & 400 & 2122 & 13 & $\begin{array}{l}29.41 \pm \\
3.28\end{array}$ & $\begin{array}{l}19.45 \pm \\
2.13\end{array}$ & LD & $\begin{array}{l}30.02 \pm \\
3.16 \mathrm{a}\end{array}$ & $\begin{array}{l}1.12 \pm \\
0.04 a\end{array}$ & $\begin{array}{l}6.78 \pm \\
0.15 a\end{array}$ & $\begin{array}{l}3.17 \pm \\
0.29 \mathrm{a}\end{array}$ & $\begin{array}{l}0.9 \pm \\
0.08 a\end{array}$ \\
\hline & & 600 & 2128 & 15 & $\begin{array}{l}29.78 \pm \\
3.43\end{array}$ & $\begin{array}{l}18.93 \pm \\
1.34\end{array}$ & & & & & & \\
\hline & & 725 & 2140 & 26 & $\begin{array}{l}27.52 \pm \\
3.27\end{array}$ & $\begin{array}{l}18.62 \pm \\
3.66\end{array}$ & & & & & & \\
\hline & & 875 & 2160 & 18 & $\begin{array}{l}28.06 \pm \\
2.54\end{array}$ & $\begin{array}{l}18.58 \pm \\
2.07\end{array}$ & $\mathrm{MD}$ & $\begin{array}{l}32.17 \pm \\
3.24 a\end{array}$ & $\begin{array}{l}1.08 \pm \\
0.07 a\end{array}$ & $\begin{array}{l}7.03 \pm \\
0.10 \mathrm{a}\end{array}$ & $\begin{array}{l}3.15 \pm \\
0.42 a\end{array}$ & $\begin{array}{l}0.92 \pm \\
0.11 \mathrm{a}\end{array}$ \\
\hline & & 975 & 2162 & 12 & $\begin{array}{l}27.16 \pm \\
3.00\end{array}$ & $\begin{array}{l}18.49 \pm \\
2.83\end{array}$ & & & & & & \\
\hline & & 1150 & 2159 & 12 & $\begin{array}{l}26.94 \pm \\
2.98\end{array}$ & $\begin{array}{l}17.93 \pm \\
2.98\end{array}$ & & & & & & \\
\hline & & 1350 & 2154 & 13 & $24.10 \pm$ & $18.14 \pm$ & $\mathrm{HD}$ & $25.28 \pm$ & $1.19 \pm$ & $7.00 \pm$ & $2.53 \pm$ & $1.48 \pm$ \\
\hline
\end{tabular}


Table 1 Summary of the characteristics of the sample plots. [N40 $\mathrm{E}],\left[\mathrm{N} 10^{\circ} \mathrm{E}\right]$, and $\left[\mathrm{N} 20^{\circ} \mathrm{E}\right]$ where $\mathrm{N}$ is the reference direction, and $40^{\circ} \mathrm{E}$ is the deviation from the reference direction heading east. SWC, soil moisture content; BD, soil bulk density; TN, soil total nitrogen content; TP, soil total phosphorus content; $\mathrm{DBH}$, diameter at breast height; $\mathrm{pH}$, hydrogen ion concentration. Values are the mean \pm standard deviation (SD). Different lowercase letters $(a, b$, and $c)$ indicate significant differences $(P<0.05)$ between different stand density levels. 27a, 27-year-old stand; 36a, 36-year-old stand; 48a, 48-year-old stand (Continued)

\begin{tabular}{|c|c|c|c|c|c|c|c|c|c|c|c|c|}
\hline $\begin{array}{l}\text { Stand } \\
\text { age }\end{array}$ & Aspect & $\begin{array}{l}\text { Stand density } \\
\text { (trees/ha) }\end{array}$ & $\begin{array}{l}\text { Elevation } \\
\text { (m) }\end{array}$ & $\begin{array}{l}\text { Slope } \\
\left({ }^{\circ}\right)\end{array}$ & $\begin{array}{l}\text { DBH } \\
(\mathrm{cm})\end{array}$ & $\begin{array}{l}\text { Height } \\
\text { (m) }\end{array}$ & $\begin{array}{l}\text { Stand density } \\
\text { level }\end{array}$ & SWC (\%) & $\begin{array}{l}\mathrm{BD}(\mathrm{g} / \\
\left.\mathrm{cm}^{3}\right)\end{array}$ & $\mathrm{pH}$ & $\begin{array}{l}\mathrm{TN}(\mathrm{g} / \\
\mathrm{kg})\end{array}$ & $\begin{array}{l}\mathrm{TP}(\mathrm{g} / \\
\mathrm{kg})\end{array}$ \\
\hline & & & & & 2.81 & 2.51 & & $0.92 b$ & $0.11 a$ & $0.07 a$ & $0.51 a$ & $0.41 b$ \\
\hline & & 1475 & 2136 & 16 & $\begin{array}{l}23.58 \pm \\
2.76\end{array}$ & $\begin{array}{l}17.91 \pm \\
2.36\end{array}$ & & & & & & \\
\hline & & 1625 & 2140 & 15 & $\begin{array}{l}21.03 \pm \\
2.56\end{array}$ & $\begin{array}{l}17.85 \pm \\
1.73\end{array}$ & & & & & & \\
\hline
\end{tabular}

\section{Variabilities in Rs, Rh, and Ra for different stand density levels}

For the 27a stand, the Rh of MD was significantly higher than that of HD and slightly higher than LD, whereas the Rs of MD was slightly higher than that of $L D$ and $\mathrm{HD}$. The Ra of HD was the highest, followed by MD, and LD was the lowest. For the 36a stand, the Rh of MD was significantly higher than that of HD and slightly higher than LD, whereas the Rs of MD was significantly higher than the other two grades, and there was no significant difference in the Ra. For the 48a stand, the Rs of MD was significantly higher than HD and LD, whereas the Rh was slightly higher than LD and higher than HD. The Ra of MD was significantly higher than LD and HD (Fig. 2).

Variations in Rs, Rh, and Ra for differently aged stands and stand density levels

We attempted to characterize the variations in Rs, Rh, and $\mathrm{Ra}$ for the stands with ages and stand density using regression analyses (Fig. 3). The quadratic function was employed to fit the changing trends of the Rs, $\mathrm{Rh}$, and $\mathrm{Ra}$ at different ages, and this function fitted the data well, as it described the stand density variations for the Rs and $\mathrm{Rh}$ by more than $50 \%\left(R^{2}>0.5\right)$. Older stands had higher Rs and Rh rates; however, when the stand density was too great, the Rs and Rh of the three differently aged stands were identical. The model curve of the quadratic function appeared to be highest at the same time, maintaining higher Rs and $\mathrm{Rh}$ levels for the $48 \mathrm{a}$ stand, followed by the 36a stand. This indicated that the older stand was more sensitive to stand density. In terms of autotrophic respiration, except for the 48a stand, the autotrophic respiration of the $36 \mathrm{a}$ and $27 \mathrm{a}$ stands showed a clear upward trend with higher stand densities.

We endeavored to further investigate the kinetics of the effects of stand density on Rs, once the effects of stand density on different aged Larix principisrupprechtii plantations were clarified. Consequently, we used the $\mathrm{R}$ 4.0.3 Lavan package to establish the structural equation model (SEM) for the four observed

Table 2 Analytical results of the factors affecting Rs, Rh, Ra, and soil labile organic carbon. In the table, asterisk represents statistical significance, in which ${ }^{*} P<0.05,{ }^{*} P<0.01$, and ${ }^{* *} P<0.001$. Rs, soil respiration; Rh, heterotrophic respiration; Ra, autotrophic respiration; SOC, soil organic carbon; DOC, soil dissolved organic carbon; MBC, microbial biomass carbon; LFOC, light fraction organic carbon; ROC, readily oxidized carbon

\begin{tabular}{|c|c|c|c|c|c|c|}
\hline \multirow[t]{2}{*}{ Factor } & \multicolumn{2}{|c|}{ Stand density } & \multicolumn{2}{|c|}{ Stand age } & \multicolumn{2}{|c|}{ Stand age $\times$ stand density } \\
\hline & $F$ value & $P$ value & $F$ value & $P$ value & $F$ value & $P$ value \\
\hline Rs & 8.002 & $0.010^{*}$ & 2.488 & 0.107 & 1.323 & 0.287 \\
\hline Rh & 12.987 & $0.002^{* *}$ & 2.577 & 0.099 & 0.691 & 0.512 \\
\hline Ra & 0.038 & 0.847 & 2.411 & 0.114 & 0.958 & 0.400 \\
\hline SOC & 151.631 & $<0.001^{* * *}$ & 72.849 & $<0.001^{* * *}$ & 0.722 & 0.498 \\
\hline $\mathrm{ROC}$ & 3.174 & 0.089 & 9.225 & $0.001^{* *}$ & 0.24 & 0.788 \\
\hline$M B C$ & 18.382 & $<0.001^{* * *}$ & 12.163 & $<0.001^{* * *}$ & 0.433 & 0.654 \\
\hline DOC & 364.062 & $<0.001^{* * *}$ & 469.313 & $<0.001^{* * *}$ & 3.501 & $0.048^{*}$ \\
\hline LFOC & 67.413 & $<0.001^{* * *}$ & 24.824 & $<0.001^{* * *}$ & 4.059 & $0.032^{*}$ \\
\hline
\end{tabular}




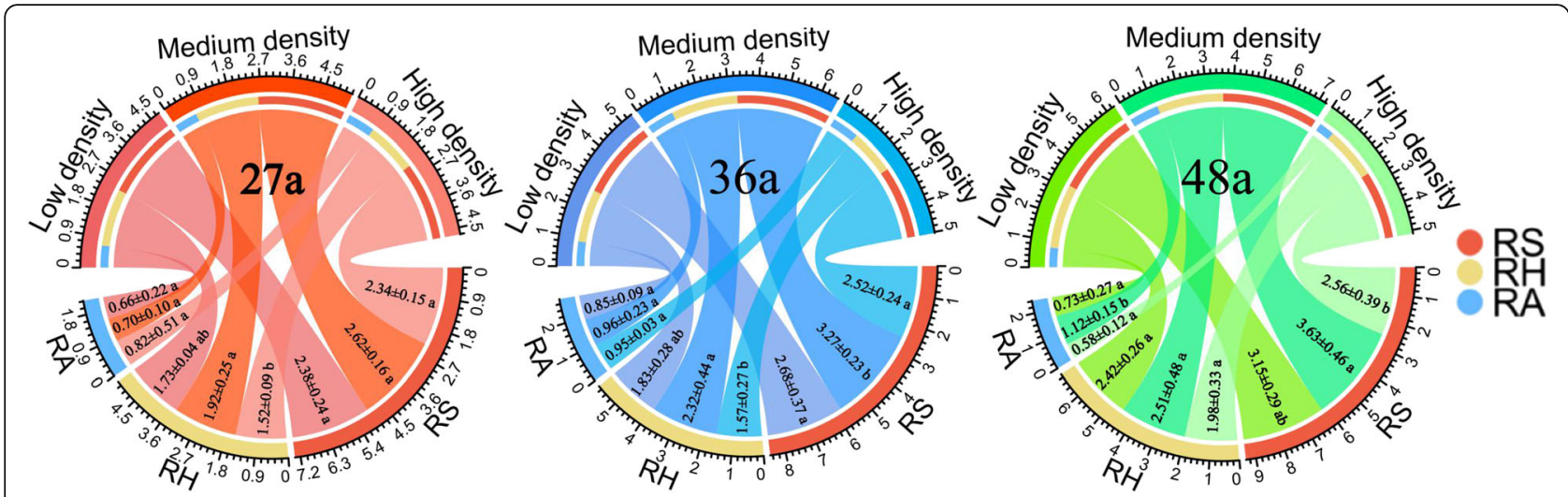

Fig. 2 Rs, Rh, and Ra for differently aged stands and stand density levels. Values are the mean \pm standard deviation (SD). Different lowercase letters $(a, b$, and $c)$ indicate significant differences $(P<0.05)$ between different stand density levels. Rs, soil respiration; Rh, heterotrophic respiration; Ra, autotrophic respiration. 27a, 27-year-old stand; 36a, 36-year-old stand; 48a, 48-year-old stand
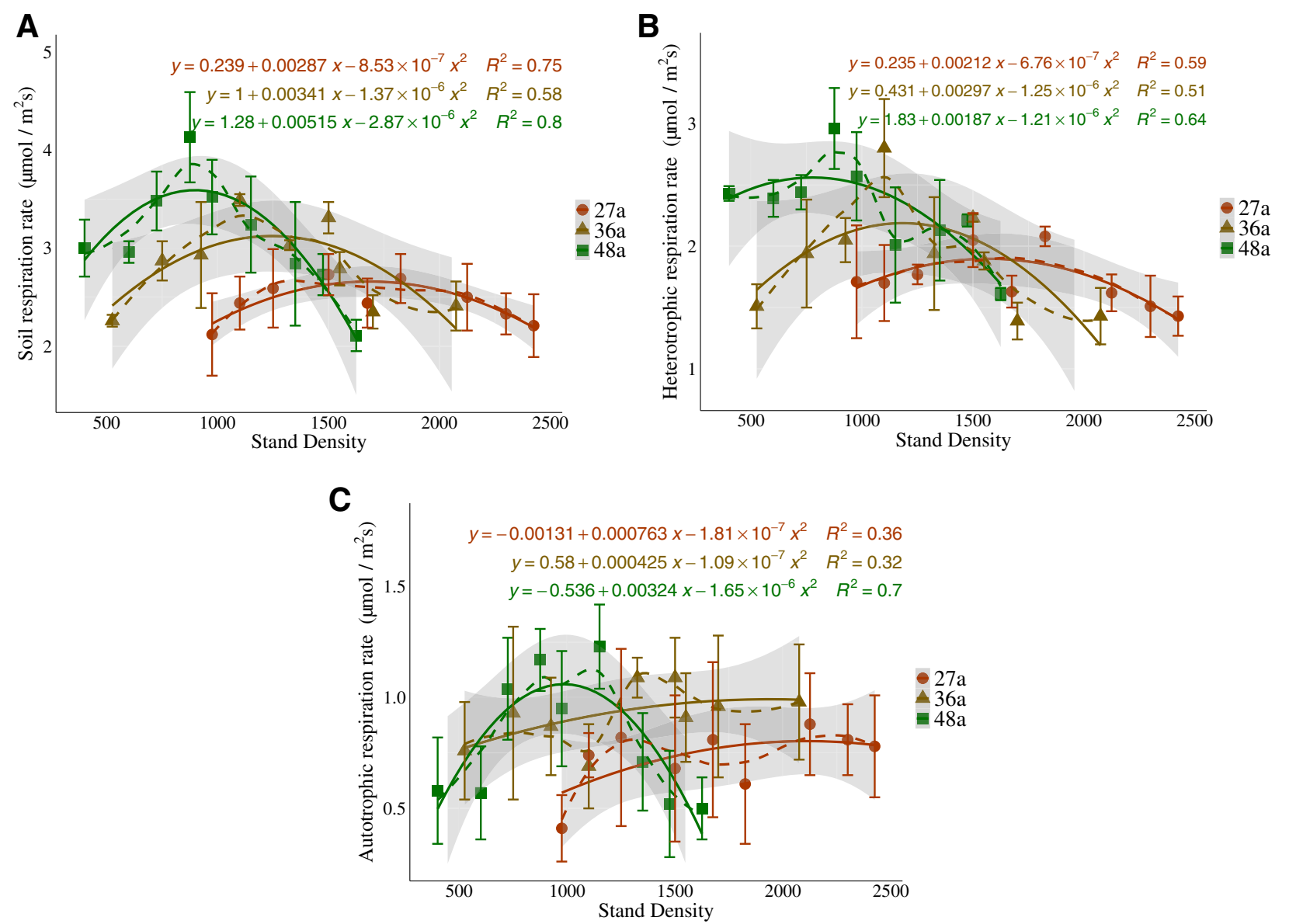

Fig. 3 Variations in the Rs, Rh, and Ra of the differently aged stands and densities. Error bars show the standard deviation (SD). Shaded areas represent confidence intervals. 27a, 27-year-old stand; 36a, 36-year-old stand; 48a, 48-year-old stand 
variables of the three different aged stands. It was found that Lavaan typically ended after 60 iterations, and the model's $P$ value $\left(P=0.653, X^{2}=1.628, C F I=1.000\right)$ was greater than 0.05 ; thus, the structural equation model was acceptable. We found that the influences of the densities of Larix principis-rupprechtii plantations on soil respiration at different ages were primarily derived from the regulation of heterotrophic respiration, with a small portion coming from the regulation of autotrophic respiration (Fig. 4). The direct effect of heterotrophic respiration on soil respiration was 0.84 , whereas for autotrophic respiration, it was 0.64 .

\section{Effects of stand density on the SOC and labile organic carbon}

We separately analyzed the differences between the SOC, MBC, DOC, LFOC, and ROC at different density levels. We employed the advantages of the density sequence plots to identify the trends of these indicators with stand density.

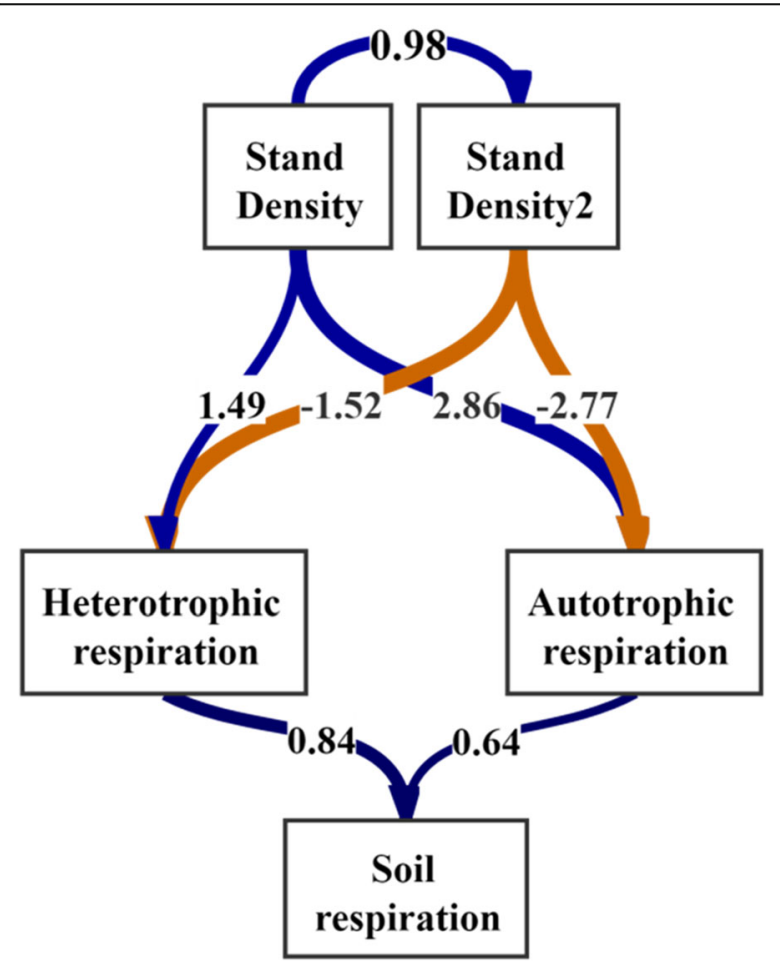

Fig. 4 Structural equation model of the influencing mechanism of stand density on Rh, Ra, and Rs. Stand density 2 is the square of the stand density; all lines are direct effects, the brown line is a negative effect, and the blue line is a positive effect. Note: according to previous results, it was found that the relationship between soil respiration and forest density was not a simple linear relationship. Therefore, the stand density square was introduced to construct a structural equation model, which made the model more meaningful
SOC, MBC, DOC, LFOC, and ROC of different stand ages and stand density levels

No significant differences were found in the SOC of the three differently aged stands between the various stand density levels (Table 3). For the 27a stand, the $\mathrm{MBC}$ of MD was slightly higher than that of LD and significantly higher than HD, whereas the DOC had no significant difference. The LFOC of MD and $\mathrm{LD}$ was significantly higher than HD, and the ROC had no significant difference; however, the ROC of $\mathrm{MD}$ was lower than LD and HD.

For the 36a stand, the MBC of MD was significantly higher than that of LD and HD, and there was no significant difference in the DOC. The LFOC of LD and MD was significantly higher than that of $\mathrm{HD}$, and there was no significant difference in the ROC; however, the ROC of MD was lower than that of LD and HD. For the 48a stand, the MBC of MD was significantly higher than that of HD and slightly higher than that of LD. The DOC of LD was slightly higher than that of MD and significantly higher than HD.

\section{Variation of SOC and labile organic carbon with stand density at different stand ages}

The SOC of the different aged stands revealed a downward trend with stand density changes, which could be adequately described by linear regression. Although the SOC of each stand age increased with stand density, the SOC remained high for the 48a stands, followed by the 36a stands, with the lowest for the 27a stands (Fig. 5a). The DOC did not exhibit an obvious trend with stand density (Fig. 5b). The LFOC of the three different age stands initially increased and then decreased with greater stand densities. The trend of the 48a stand was the most obvious, whereas the changes for the 36a and 27a stands were insignificant (Fig. 5c). The tendency of the soil ROC changes was opposite to that of the LFOC, and the initial trend of the soil ROC of the three different aged stands exhibited a decrease and then an increase (Fig. 5d). The soil MBC initially increased and then decreased with greater stand density. The MBC content of the $48 \mathrm{a}$ stands was reduced to $400 \mathrm{mg} / \mathrm{kg}$ when the stand density was greater than 1300 trees/ha, which was lower than the 36a stand with a similar density (Fig. 5e).

Based on these trends, we concluded that although the general tendency of the SOC and soil labile organic carbon affected by density was the same in the different aged stands, there were several differences in their sensitivity to changes in stand density. For the 48 a stand, the density change response is the strongest, which was particularly reflected in the LFOC, ROC, and MBC. For the 27a stand, the response was weaker than that of the 36a and 48a stands, and the range of variation with stand density was rather small. 
Table 3 Soil analysis results for SOC and labile organic carbon at 0-30 cm soil depth for different stand density levels. Values are the mean \pm standard deviation (SD). Different lowercase letters $(a, b, c)$ indicate significant differences between stand density levels $(P<$ 0.05). SOC, soil organic carbon; DOC, soil dissolved organic carbon; MBC, microbial biomass carbon; LFOC, light fraction organic carbon; ROC, readily oxidized carbon. 27a, 27-year-old stand; 36a, 36-year-old stand; 48a, 48-year-old stand

\begin{tabular}{|c|c|c|c|c|c|c|}
\hline Stand age & Stand density level & SOC (g/kg) & $\mathrm{MBC}(\mathrm{mg} / \mathrm{kg})$ & $\mathrm{DOC}(\mathrm{mg} / \mathrm{kg})$ & LFOC (mg/kg) & $\mathrm{ROC}(\mathrm{mg} / \mathrm{kg})$ \\
\hline \multirow[t]{3}{*}{$27 a$} & LD & $14.19 \pm 1.56 a$ & $286.37 \pm 18.89 a b$ & $196.42 \pm 15.17 a$ & $381.53 \pm 9.89 a$ & $1328.85 \pm 100.73 a$ \\
\hline & $\mathrm{MD}$ & $14.21 \pm 0.41 a$ & $308.94 \pm 4.17 a$ & $206.48 \pm 5.71 a$ & $379.92 \pm 14.00 a$ & $1298.91 \pm 240.39 a$ \\
\hline & $\mathrm{HD}$ & $12.03 \pm 1.77 a$ & $263.93 \pm 21.01 b$ & $191.90 \pm 2.69 a$ & $351.99 \pm 6.51 b$ & $1503.01 \pm 73.66 a$ \\
\hline \multirow[t]{3}{*}{$36 a$} & LD & $19.83 \pm 1.62 \mathrm{a}$ & $402.62 \pm 29.44 a$ & $257.88 \pm 9.94 a$ & $419.48 \pm 5.43 a$ & $1651 \pm 72.05 a$ \\
\hline & MD & $19.33 \pm 0.79 a$ & $455.49 \pm 3.51 b$ & $258.21 \pm 13.72 a$ & $426.35 \pm 10.62 a$ & $1321.13 \pm 281.17 a$ \\
\hline & $\mathrm{HD}$ & $17.88 \pm 0.14 a$ & $384.30 \pm 33.61 a$ & $260.66 \pm 6.52 a$ & $403.21 \pm 4.67 \mathrm{~b}$ & $1636.35 \pm 82.91 a$ \\
\hline \multirow[t]{3}{*}{$48 a$} & LD & $24.96 \pm 1.58 a$ & $441.18 \pm 71.05 \mathrm{ab}$ & $364.68 \pm 4.20 \mathrm{a}$ & $501.76 \pm 13.60 a$ & $2302.76 \pm 83.38 a$ \\
\hline & MD & $22.67 \pm 2.32 \mathrm{a}$ & $533.82 \pm 81.96 a$ & $355.39 \pm 14.31 \mathrm{ab}$ & $523.81 \pm 16.39 a$ & $1548.48 \pm 286.68 b$ \\
\hline & $\mathrm{HD}$ & $22.16 \pm 0.55 a$ & $381.57 \pm 14.75 b$ & $345.63 \pm 2.64 b$ & $419.88 \pm 5.36 b$ & $2200.04 \pm 343.99 a$ \\
\hline
\end{tabular}

\section{Correlations between soil organic carbon, labile organic carbon, and soil respiration}

We further investigated whether there were certain correlations between soil respiration and soil labile organic carbon with the background of stand density regulation (Fig. 6). Correlation analysis revealed that the Rs was significantly negatively correlated with the ROC and significantly positively correlated with the DOC, LFOC, and $\mathrm{MBC}$. Further, the Rh was significantly negatively correlated with the ROC, SOC, and MBC. For the 36a stand, the $\mathrm{Rs}$ and $\mathrm{Rh}$ indicated a negative correlation with the ROC, a strong positive correlation with the MBC and LFOC, and a significantly positive correlation between the $\mathrm{Ra}$ and DOC. For the 48a stand, the Rs was significantly positively correlated with the MBC, LFOC, and DOC but significantly negatively correlated with the ROC. The Rh and the SOC, MBC, DOC, and LFOC were significantly positively correlated; however, the $\mathrm{Rh}$ was substantially negatively correlated with the ROC. The $\mathrm{Ra}$ was significantly positively correlated with the $\mathrm{MBC}$ and LFOC and appreciably negatively correlated with the ROC.

\section{Explanation of soil organic carbon pool in the variability of soil respiration}

Once we understood the correlations between the SOC, soil labile organic carbon, and soil respiration, we conducted the redundant analyses of soil respiration and soil organic carbon using the SOC and soil labile organic carbon to explain the variations in the soil respiration rate. Axes 1 and 2 described 99.99\% of the variations of interest, which strongly represented the original explanatory variable. RDA1 and RDA2 contained almost all of the axes data and jointly explained $56.05 \%$ of variances in the Rs, Rh, and Ra (Fig. 7).

\section{Discussion}

Effects of stand density on soil respiration of different aged stands

The Rs and $\mathrm{Rh}$ of the various stand density levels revealed significant differences (Fig. 2). The Rs and Rh of MD were higher than LD and HD, whereas the Ra of the 48a stand was significantly higher than LD and HD; however, there were no significant differences in the Ra for the other two stand ages. We considered that for the three stand ages, the moderate stand density promoted the Rs and Rh. We combined the tendencies of the Rs, $\mathrm{Rh}$, and $\mathrm{Ra}$ to derive a reasonable explanation.

The Rs and Rh initially increased and then decreased with higher stand densities. This trend was well fitted by the quadratic function (Fig. 3), which was also reported in previous studies and coincided with the idea of the Intermediate-Disturbance Hypothesis (Connell 1979). However, it appeared that most of the research conclusions were limited to positing that thinning significantly improved forest soil respiration, whereas different thinning intensities (retention densities) exhibited variable enhancements. Specifically, appropriate reductions in the stand density increased the Rs and Rh (Zhang et al. 2018; Shao et al. 2017; Lei et al. 2018), which was similar to what we found in our study. The only difference was that the Rs and Rh initially increased and then decreased with stand density; they could not maintain high levels when the stand density was too low.

We assumed that there may have been two reasons for this, including that the soil microenvironments created by low stand densities and upper shading might not be suitable for the activities of soil microbes (Yang et al. 2017). Further, low-density stand litter may have not been appropriate for soil microbial activities, and the amount returned was less than that of high-density stands, which resulted in the limitation of organic 


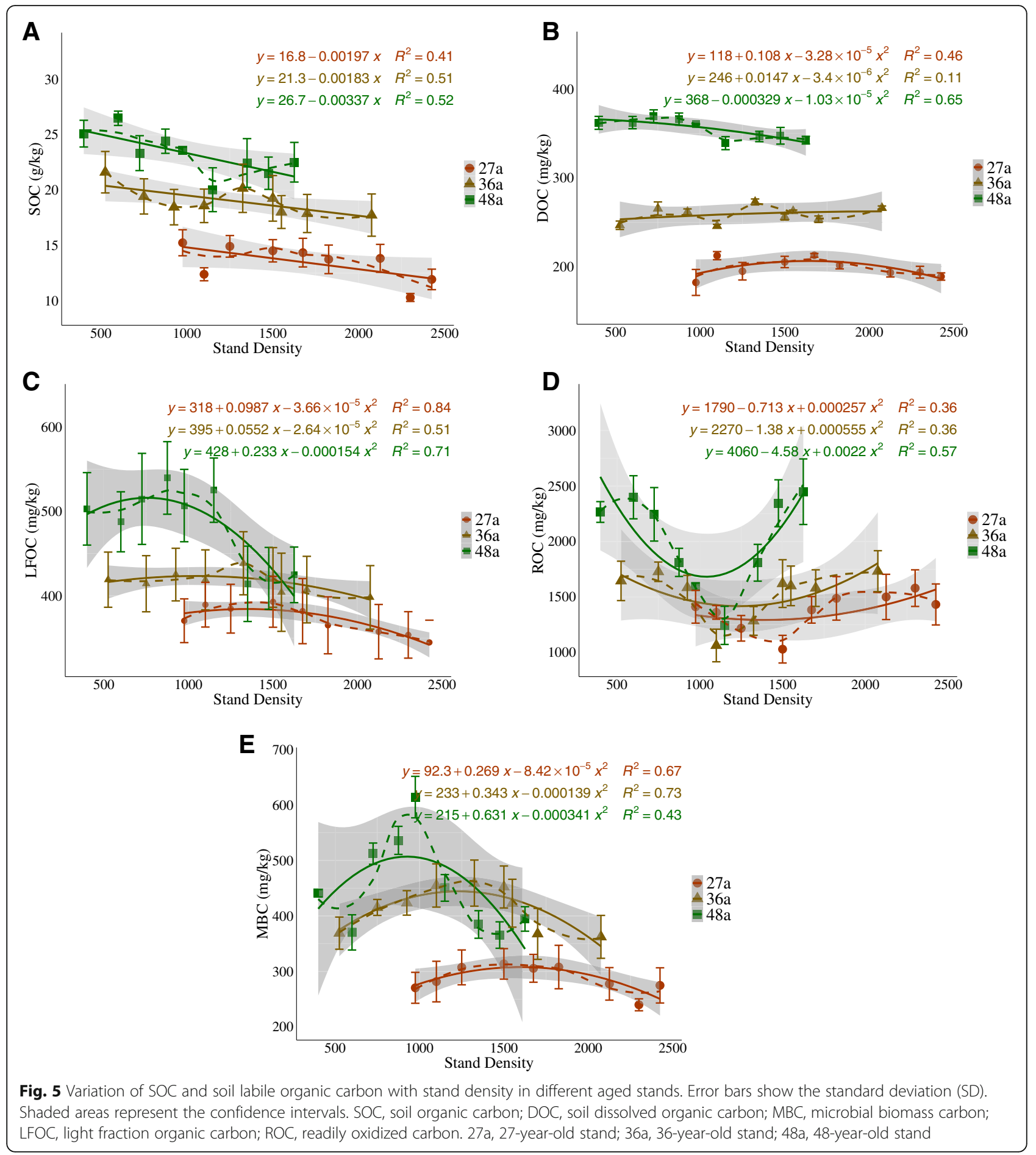

carbon components as respiratory substrates in some soil carbon pools. The Ra trend for the 48a stands with different stand densities was similar to the Rs and Rh, and the Ra showed an upward trend with stand density for the 36a and 27a stands (Fig. 3c).

We considered that there was a threshold for the capacity of the soil to hold plant roots, where an increase in the root density within this threshold induced an increase in autotrophic soil respiration. This was the reason behind the increase in autotrophic soil respiration for the 27a and 36a stands, whereas for the 48a plantations, excessive forest stand densities caused the root density to exceed this threshold. Plant roots and root microbes compete fiercely (Grubb 2000), which can lead 


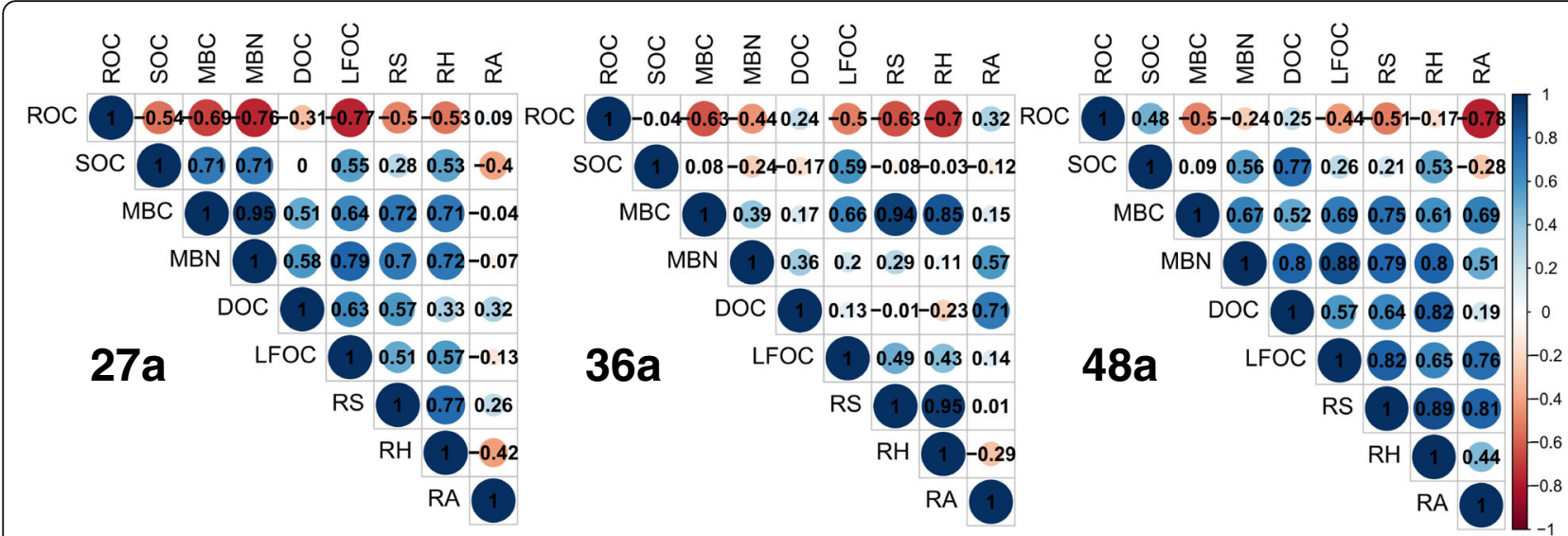

Fig. 6 Correlations between the Rs, Rh, Ra, and the SOC and soil labile organic carbon for different aged stands. SOC, soil organic carbon; DOC, soil dissolved organic carbon; MBC, microbial biomass carbon; LFOC, light fraction organic carbon; ROC, readily oxidized carbon; Rs, soil respiration; Rh, heterotrophic respiration; Ra, autotrophic respiration. 27a, 27-year-old stand; 36a, 36-year-old stand; 48a, 48-year-old stand

to reduced root microbial activity, root death, and even plant death (Kuzyakov and Larionova 2005). Thus, for the 48a stand, the soil Ra initially increased and then decreased with higher stand densities.

The trends appearing in the Rs, Rh, and Ra were significantly age-related (Fig. 3), where the fastest was in the 48-year-old stand, followed by the 36-year-old stand, and slowest in the 27-year-old stand (Gao et al. 2019; $\mathrm{Wu}$ et al. 2020; Yu et al. 2019). However, several researchers obtained different results; they found that soil respiration decreased with advancing stand age, where the decline of soil resident fine root biomass may have been the cause (Saiz et al. 2006). We found that in forests with positive succession, soil microorganisms played an enhanced role as decomposers with advanced forest age, due to the accumulation of more organic matter and the improvement of the soil microenvironment, to promote redox processes in the soil (You et al. 2014; Shrestha et al. 2014). Consequently, this caused differences in the soil and heterotrophic respiration rates, which increased with advancing stand age.

The regulatory mechanism of stand density on Rs was that the stand density primarily mediated soil respiration by altering the $\mathrm{Rh}$ and then regulating the $\mathrm{Ra}$, which was empirically verified by the structural equation model (Fig. 4). Changes in the Ra and its effects on soil respiration were weaker than heterotrophic respiration (BondLamberty et al. 2004). The reason may have been that the status of the soil organic carbon and the soil microenvironment of different stand densities were variable.

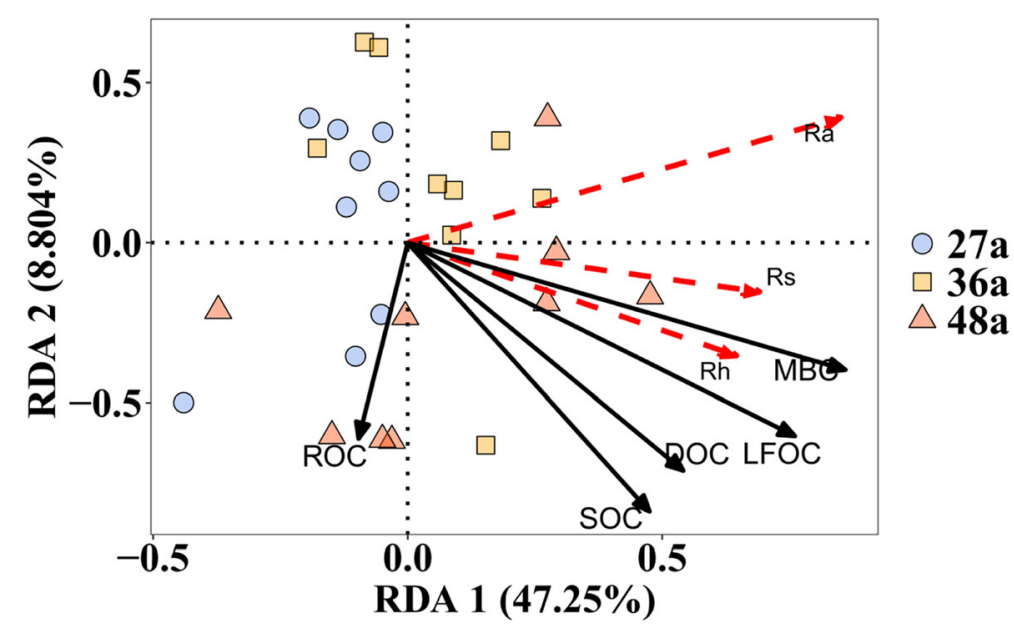

Fig. 7 Redundancy analysis (RDA) to determine the effects of the selected soil organic carbon factor (black arrows) on soil respiration (red arrows). SOC, soil organic carbon; DOC, soil dissolved organic carbon; MBC, microbial biomass carbon; LFOC, light fraction organic carbon; ROC, readily oxidized carbon; Rs, soil respiration; Rh and heterotrophic respiration; Ra, autotrophic respiration. 27a, 27-year-old stand; 36a, 36-year-old stand; 48a, 48-year-old stand 
In other words, from the perspective of soil respiration mechanisms, the state of the substrate, enzyme activity process, temperature, and humidity may have differences, which are also the major factors that affect the $\mathrm{Rh}$.

\section{Effects of stand density on the SOC and labile organic carbon in different aged stands}

Numerous studies have confirmed that soil depth significantly impacts organic carbon and soil nutrients; thus, it does not appear in the discussion of this study (Baldrian et al. 2012). We observed for the three different aged stands that the variations in soil labile organic carbon at different stand density levels were primarily reflected by three indicators: $M B C$, LFOC, and ROC. Among these, the MBC and LFOC of MD were significantly higher than for LD and HD, whereas the ROC was lower than LD and HD. In other words, moderate stand density promoted the accumulation of the MBC and LFOC, while inhibiting the accumulation of ROC. It is known that the SOC might increase with lower stand density to a certain extent.

Although lower stand densities increase the loss of litter (Lim et al. 2012; Lull et al. 2020), appropriate soil environments enhance the rate of biochemical processes, thus promoting the increase of SOC, which was consistent with the conclusion of this study. It is not difficult to find the explanation through the composition of LFOC and MBC. The composition of LFOC is typically soil organic matter with a soil particle density of less than $2.0 \mathrm{~g} / \mathrm{cm}^{3}$ (Wu et al. 2003), comprising mainly animal and plant residues, mycelium, spores, monosaccharide, polysaccharide, and hemilignin (Christensen 1992; Christensen, 2001).

The MBC refers to the total $\mathrm{C}$ content of living bacteria, fungi, algae, and soil microorganisms in the soil (Wander et al. 1994). When the stand density was moderate, the soil microenvironment was more suitable for microbes, where the population of soil microorganisms, their activities, and associated intermediate products were increased. Therefore, the contents of LFOC and MBC were highest when the density was moderate, which showed a tendency to initially increase and then decrease. This could be well fitted by the quadratic function, whereas the DOC had no obvious correlation with the stand density. The DOC is an element of organic carbon in the soil that can be dissolved in water via extraction, including simple organic molecules such as carbohydrates, amino acids, and small molecular proteins (Bolan et al. 2008). The DOC has strong mobility, which is more robust during rainy summers; thus, it would not be affected by higher stand density. The reason behind changes in the ROC is explained in the following discussion combined with soil respiration.

According to the changing trend of SOC and soil labile organic carbon with stand density, the SOC, MBC, LFOC, DOC, and ROC maintained the highest content in $48 \mathrm{a}$ stands, followed by 36a stands, with the lowest in 27a stands. On one hand, this was due to the carbon fixation of plants during the process of plantation growth and continuous $\mathrm{C}$ inputs into the soil carbon pool through litter. Conversely, the continuous development of tree roots directly increases soil organic carbon, which indirectly affects the fixation of soil water and nutrients (Strong and Roi 1983; Teskey et al. 1985; Andrew et al. 2008). This improved the soil microenvironment to a certain degree, and the soil microbial activity was promoted. Therefore, the SOC content and soil labile organic carbon increased with age.

\section{Sensitivity of soil carbon pool indicators of forest stands of different ages to changes in density}

Soil respiration, SOC, and soil labile organic carbon are influenced by forest density to varying degrees (Figs. 3 and 5). However, the sensitivity of forests of different ages to density is variable, particularly for the ROC, LFOC, and MBC indicators. From the perspective of the change range and fitting equation, the change range of the 48a forest stands affected by density was obviously larger than that of 36a and 27a stands, respectively. We considered that the older the plantation, the greater the importance of individual trees in the sample plot. This was reflected by the larger crown width, root area, etc. The death or felling of each tree in the sample plot will have a more significant impact on the soil and upper shading, whereas density changes have a stronger effect on the forest soil microenvironment. Therefore, soil respiration and labile organic carbon will exhibit strong sensitivity.

\section{Relationship between soil labile organic carbon and soil respiration}

Through correlation analysis, we clearly observed that the Rs, Rh, MBC, LFOC, and ROC exhibited strong correlations, which was positive with and $\mathrm{MBC}$ and $\mathrm{LFOC}$ and negative with ROC (Fig. 6). However, the correlation between the $\mathrm{Ra}$ and soil labile organic carbon for the 48a stands did not have much practical meaning. The trend of Ra was largely determined by the stand and root density.

Readily oxidized carbon (ROC) in the soil is rapidly oxidized and decomposed by microorganisms and soil enzymes. We can understand that LFOC is similar to a "warehouse" of soil respiration, whereas MBC is more akin to a "tool". This is a feature evolved through the 
long-term cumulative effects of different stand densities, where ROC is more like a "raw material", which is an immediate feature. We considered that ROC decomposed over time at a higher soil respiration rate and remained dynamically stable with lower content. In contrast, it revealed dynamic stability with higher content when the soil respiration rate was lower. Therefore, the ROC was negatively correlated with the Rs and Rh, which also explained the trend that the ROC initially decreased and then increased with stand density. Because more powerful "tools" should support the high rate of soil respiration, the LFOC, MBC, Rs, and Rh showed significantly positive correlations. This allowed us to link the relationship between labile organic carbon and soil respiration, where the results of RDA also proved this point well. We found that the SOC and soil labile organic carbon had a high degree of explanation (56.05\%) for the variations in $\mathrm{Rs}, \mathrm{Rh}$, and $\mathrm{Ra}$.

On one hand, stand density affected the soil microenvironment such as temperature and humidity. On the other hand, it regulated the state and content of labile organic carbon in the soil carbon pool and affected soil respiration from another aspect. That is, stand density was related to soil labile organic carbon respiration, which is also a critical path of stand density that regulates soil respiration LFOC, MBC, and ROC in carbon components, which are responsible for the "warehouse," "tools", and "raw materials". We speculated that enzymes related to the soil $\mathrm{C}$ cycle played the role of controlling the speed and, further, whether the existing Rs model might be improved by using the characteristics of labile organic carbon (respiration substrate characteristics) and enzyme activity (rate characterization), so as to make the model more ecological and scientific, which will be the focus of our future study.

Although the following is a statement with substantial limitations, it may be considered an essential reference and guidance for regional forest management. Taking an afforestation density of 3300 plants/ha as an example, a forest stand of 27 years old should maintain $~ 1650$ plants/ha (50\%), and a forest stand of 36 years old should accommodate $\sim 1250$ plants/ha (38\%), whereas a forest stand of 48 years old should be maintained at $~ 900$ plants/ha (27\%). This is so that both the aboveground vegetation carbon pool and soil carbon storage/sequestration can be maintained at a high level, while the soil labile organic carbon content is also at a high level and stable, soil microbial activity is high, and soil quality is good.

\section{Conclusion}

During the growth and development of plantations, stand density is an essential factor that affects soil respiration and its associated elements. Stand density affects both $\mathrm{Rh}$ and $\mathrm{Ra}$; however, it primarily influences Rs by regulating $\mathrm{Rh}$. Moderate stand density can promote the soil and heterotrophic respiration rates at each developmental stage of the plantation.

There are certain variations in the form and content of organic carbon for different stand densities. Moderate stand density promotes the sequestration of $\mathrm{MBC}$ and LFOC and inhibits the sequestration of ROC. In older forest stands, the sequestration of labile organic carbon and the soil respiration rate are more sensitive to stand density.

In the soil carbon pool, active organic carbon is intimately related to soil respiration, and not the content of soil organic carbon. Among them, the LFOC and MBC play the role of "warehouse" and "tool", and significantly correlate with Rs and Rh. As a "raw material", the ROC has a significant negative correlation with Rs and Rh. When the Rh and Rs rates are fast, the dynamic lowlevel stability is maintained. We considered that stand density regulated the $\mathrm{Rh}$ by affecting the soil labile organic carbon, which is an essential path for stand density to regulate soil respiration.

\section{Abbreviations}

BD: Bulk density; SWC: Soil moisture content; TN: Soil total nitrogen content; TP: Soil total phosphorus content; PVC: Polyvinyl chloride; DBH: Diameter at breast height; $\mathrm{pH}$ : Hydrogen ion concentration; LD: Low density;

MD: Medium density; HD: High density; Rs: Soil respiration; Rh: Heterotrophic respiration; Ra: Autotrophic respiration; SOC: Soil organic carbon; MBC: Microbial biomass carbon; LFOC: Light fraction organic carbon; DOC: Dissolved organic carbon; ROC: Readily oxidized carbon

\section{Acknowledgements}

We gratefully acknowledge the support of the Xiaowenshan Forest Farm for fieldwork. We also thank the colleagues for the assistance with field measurements and laboratory work.

\section{Authors' contributions}

Tairui Liu: conceptualization, formal analysis, investigation, data curation, writing —original draft, and writing — review and editing. Daoli Peng: conceptualization, resources, supervision, project administration, and funding acquisition. Zhijie Tan: investigation, data curation, validation, and visualization. Jingping Guo: investigation, data curation, and resources. Yunxiang Zhang: resources. The authors read and approved the final manuscript.

\section{Funding}

This research was funded by the National Key Research and Development Program of China (2016YFD0600205).

\section{Availability of data and materials}

Not applicable.

\section{Declarations}

Ethics approval and consent to participate

Not applicable.

Consent for publication

Not applicable.

Competing interests

The authors declare that they have no competing interests. 


\section{Author details}

${ }^{1}$ College of Forestry, Beijing Forestry University, No. 35 Tsinghua East Road, Haidian District, Beijing 100083, People's Republic of China. ${ }^{2}$ Lvliang Bureau of Planning and Natural Resources, Lüliang 033000, People's Republic of China. ${ }^{3}$ College of Forestry, Shanxi Agricultural University, Jingzhong 030801, People's Republic of China.

Received: 14 January 2021 Accepted: 16 April 2021

Published online: 23 June 2021

\section{References}

Akburak S, Makineci E (2016) Thinning effects on soil and microbial respiration in a coppice-originated Carpinus betulus L. stand in Turkey. iForest Biogeosci Forestry 9(5):783-790. https://doi.org/10.3832/ifor1810-009

Ali A, Dong D, Akhtar K, Teng M, Yan Z, Urbina-Cardona N, Mullerova J, Zhou Z (2019) Response of understory vegetation, tree regeneration, and soil quality to manipulated stand density in a Pinus massoniana plantation. Glob Ecol Conserv 20:e00775. https://doi.org/10.1016/j.gecco.2019.e00775

Burton AJ, Melillo JM, Frey SD (2008) Adjustment of forest ecosystem root respiration as temperature warms. J Integr Plant Biol

Baggs EM (2006) Partitioning the components of soil respiration: a research challenge. Plant Soil 284(1-2):1-5. https://doi.org/10.1007/s11104-006-0047-7

Bai SH, Dempsey R, Reverchon F, Blumfield TJ, Ryan S, Cernusak LA (2016) Effects of forest thinning on soil-plant carbon and nitrogen dynamics. Plant Soil 411(1-2):437-449. https://doi.org/10.1007/s11104-016-3052-5

Baldrian P, Kolarik M, Stursova M, Kopecky J, Valaskova V, Vetrovsky T, Zifcakova L et al (2012) Active and total microbial communities in forest soil are largely different and highly stratified during decomposition. ISME J 6(2):248-258. https://doi.org/10.1038/ismej.2011.95

Bello J, Vallet P, Perot T, Balandier P, Seigner V, Perret S, Couteau C, Korboulewsky N (2019) How do mixing tree species and stand density affect seasonal radial growth during drought events? Forest Ecol Manage 432:436-445. https://doi. org/10.1016/j.foreco.2018.09.044

Bolan NS, Baskaran S, Thiagarajan S (2008) An evaluation of the methods of measurement of dissolved organic carbon in soils, manures, sludges, and stream water. Commun Soil Sci Plant Anal 27(13-14):2723-2737. https://doi. org/10.1080/00103629609369735

Bolat I (2013) The effect of thinning on microbial biomass C, N and basal respiration in black pine forest soils in Mudurnu, Turkey. Eur J Forest Res 133(1):131-139. https://doi.org/10.1007/s10342-013-0752-8

Bond-Lamberty B, Wang C, Gower ST (2004) A global relationship between the heterotrophic and autotrophic components of soil respiration? Glob Change Biol 10(10):1756-1766. https://doi.org/10.1111/j.1365-2486.2004.00816.x

Brookes PC, Andrea L, Pruden G, Jenkinson DS (1985) Chloroform fumigation and the release of soil nitrogen: a rapid direct extraction method to measure microbial biomass nitrogen in soil. Soil Biol Biochem 17(6):837-842. https:// doi.org/10.1016/0038-0717(85)90144-0

Cambardella CA, Elliott ET (1992) Particulate soil organic-matter changes across a grassland cultivation sequence. Soil Sci Soc Am J 56(3):777-783. https://doi. org/10.2136/sssaj1992.03615995005600030017x

Cheng X, Kang F, Han H, Liu H, Zhang Y (2015) Effect of thinning on partitioned soil respiration in a young Pinus tabulaeformis plantation during growing season. Agric Forest Meteorol 214-215:473-482. https://doi.org/10.1016/j.a grformet.2015.09.016

Christensen BT (1992) Physical fractionation of soil and organic matter in primary particle size and density separates. In: Stewart B.A. (eds) Advances in Soil Science, vol 20. Springer, New York, NY. https://doi.org/10.1007/978-1-4612-2 930-8_1

Christensen BT (2001) Physical fractionation of soil and structural and functional complexity in organic matter turnover. Eur I Soil Sci 52:345-353

Connell JH (1979) Intermediate-disturbance hypothesis. Science 204(4399):13441345

Dib AE, Johnson CE, Driscoll CT, Fahey TJ, Hayhoe K (2014) Simulating effects of changing climate and $\mathrm{CO}_{2}$ emissions on soil carbon pools at the Hubbard Brook experimental forest. Glob Chang Biol 20(5):1643-1656. https://doi.org/1 $0.1111 / \mathrm{gcb} .12436$

Eldegard K, Scholten J, Stokland JN, Granhus A, Lie M (2019) The influence of stand density on bilberry (Vaccinium myrtillus L.) cover depends on stand age, solar irradiation, and tree species composition. Forest Ecol Manage 432: 582-590. https://doi.org/10.1016/j.foreco.2018.09.054
Fernandez I, Álvarez-González JG, Carrasco B, Ruíz-González AD, Cabaneiro A (2012) Post-thinning soil organic matter evolution and soil $\mathrm{CO}_{2}$ effluxes in temperate radiata pine plantations: impacts of moderate thinning regimes on the forest C cycle. Can J Forest Res 42(11):1953-1964. https://doi.org/1 $0.1139 / \times 2012-137$

Franklin O, Aoki K, Seidl R (2009) A generic model of thinning and stand density effects on forest growth, mortality and net increment. Ann Forest Sci 66(8): 815. https://doi.org/10.1051/forest/2009073

Gabriel CE, Kellman L, Prest D (2018) Examining mineral-associated soil organic matter pools through depth in harvested forest soil profiles. PLoS One 13(11):e0206847. https://doi.org/10.1371/journal.pone.0206847

Gao J, Zhang Y, Song Q, Lin Y, Zhou R, Dong Y, Zhou L et al (2019) Stand agerelated effects on soil respiration in rubber plantations (Hevea brasiliensis) in southwest China. Eur J Soil Sci 70(6):1221-1233. https://doi.org/10.1111/ ejss. 12854

Goldberg SD, Zhao Y, Harrison RD, Monkai J, Li Y, Chau K, Jianchu X (2017) Soil respiration in sloping rubber plantations and tropical natural forests in Xishuangbanna, China. Agric Ecosyst Environ 249:237-246. https://doi.org/1 0.1016/j.agee.2017.08.001

Grubb CPJ (2000) Impacts of root competition in forests and woodlands: a theoretical framework and review of experiments. Ecol Monogr 70(2):171-207

Hopkins F, Gonzalez-Meler MA, Flower CE, Lynch DJ, Czimczik C, Tang J, Subke JA (2013) Ecosystem-level controls on root-rhizosphere respiration. New Phytol 199(2):339-351. https://doi.org/10.1111/nph.12271

$\mathrm{Hu}$ H, Ma H, Luo C, Hu T (2010) Forest soil organic carbon grouping and its determination method. Chin J Soil Sci 41(4):1018-1024 (in Chinese)

Jack SB, Long JN (1991) Analysis of stand density effects on canopy structure: a conceptual approach. Trees 5(1):44-49

Jens E, Morten C, Jacob, Heilmann-Clausen (2000) The structural dynamics of Suserup Skov, a near-natural temperate deciduous forest in Denmark. Forest Ecol Manage 126(2):173-189

Jíková V (2020) Soil respiration in temperate forests is increased by a shift from coniferous to deciduous trees but not by an increase in temperature. Appl Soil Ecol 154:103635. https://doi.org/10.1016/j.apsoil.2020.103635

Khan MNI, Shil MC, Azad MS, Sadath MN, Feroz SM, Mollick AS (2018) Allometric relationships of stem volume and stand level carbon stocks at varying stand density in Swietenia macrophylla King plantations, Bangladesh. Forest Ecol Manage 430:639-648. https://doi.org/10.1016/j.foreco.2018.09.002

Kuzyakov Y (2006) Response to the comments by Peter Högberg, Nina Buchmann and David J. Read on the review 'Sources of $\mathrm{CO}_{2}$ efflux from soil and review of partitioning methods' (Soil Biology \& Biochemistry 38, 425448) Object- versus method-oriented terminology. Soil Biol Biochem 38(9): 2999-3000. https://doi.org/10.1016/j.soilbio.2006.04.002

Kuzyakov Y, Larionova AA (2005) Root and rhizomicrobial respiration: a review of approaches to estimate respiration by autotrophic and heterotrophic organisms in soil. J Plant Nutr Soil Sci 168(4):503-520. https://doi.org/10.1 002/jpln.200421703

Lal R (2005) Forest soils and carbon sequestration. Forest Ecol Manage 220(1-3): 242-258. https://doi.org/10.1016/j.foreco.2005.08.015

Lei L, Xiao W, Zeng L, Zhu J, Huang Z, Cheng R, Gao S, Li MH (2018) Thinning but not understory removal increased heterotrophic respiration and total soil respiration in Pinus massoniana stands. Sci Total Environ 621:1360-1369. https://doi.org/10.1016/j.scitotenv.2017.10.092

Liang BC, Mackenzie AF, Schnitzer M, Monreal CM, Voroney PR, Beyaert RP (1997) Management-induced change in labile soil organic matter under continuous corn in eastern Canadian soils. Biol Fertil Soils 26(2):88-94. https://doi.org/1 $0.1007 / 5003740050348$

Lim H, Choi W-J, Ahn K, Lee K-H (2012) Ecosystem respiration and tree growth influenced by thinning in a red pine forest in southern Korea. Forest Sci Technol 8(4):192-204. https://doi.org/10.1080/21580103.2012.704977

Liu T, Dong W, Tan Z, Zhang Y, Guo J (2019b) Effects of different thinning intensities on competition of Larix principis-rupprechtii plantation. J Forest Environ 39(2):44-49

Liu T, Dong W, Tan Z, Zhang Y, Guo J (2019) Effects of different thinning intensities on competition of Larix principis-rupprechtii plantation. J Forest Environ 39(2): 44-49 (in Chinese)

Lull C, Bautista I, Lidón A, del Campo AD, González-Sanchis M, García-Prats A (2020) Temporal effects of thinning on soil organic carbon pools, basal respiration and enzyme activities in a Mediterranean Holm oak forest. Forest Ecol Manage 464:118088. https://doi.org/10.1016/j.foreco.2020.11 8088 
Ming A, Yang Y, Liu S, Wang H, Li Y, Li H, Nong Y et al (2018) Effects of near natural forest management on soil greenhouse gas flux in Pinus massoniana (Lamb.) and Cunninghamia lanceolata (Lamb.) Hook. plantations. Forests 9(5): 229. https://doi.org/10.3390/f9050229

Mosca E, Montecchio L, Barion G, Dal Cortivo C, Vamerali T (2017) Combined effects of thinning and decline on fine root dynamics in a Quercus robur $\mathrm{L}$. forest adjoining the Italian Pre-Alps. Ann Bot 119(7):1235-1246. https://doi. org/10.1093/aob/mcx007

Olajuyigbe S, Tobin B, Saunders M, Nieuwenhuis M (2012) Forest thinning and soil respiration in a Sitka spruce forest in Ireland. Agric Forest Meteorol 157: 86-95. https://doi.org/10.1016/j.agrformet.2012.01.016

Park BB, Lee IK, Yang HM (2009) The effects of thinning on fine root distribution and litterfall in a Pinus koraiensis plantation. J Ecol Environ 32(3):159-165

Poorter L, Frans B, Mitchell Aide T, Zambrano AMA (2016) Biomass resilience of neotropical secondary forests. Nature 530(7589):211-214. https://doi.org/10.1 038/nature16512

Qiu X, Peng D, Wang H, Wang Z, Cheng S (2019) Minimum data set for evaluation of stand density effects on soil quality in Larix principis-rupprechtii plantations in North China. Ecol Indic 103:236-247. https://doi.org/10.1016/j. ecolind.2019.04.010

Ryu S-R, Concilio A, Chen J, North M, Ma S (2009) Prescribed burning and mechanical thinning effects on belowground conditions and soil respiration in a mixed-conifer forest, California. Forest Ecol Manage 257(4):1324-1332. https://doi.org/10.1016/j.foreco.2008.11.033

Saiz G, Byrne KA, Butterbach-Bahl K, Kiese R, Blujdea V, Farrell EP (2006) Stand age-related effects on soil respiration in a first rotation Sitka spruce chronosequence in central Ireland. Glob Change Biol 12(6):1007-1020. https://doi.org/10.1111/j.1365-2486.2006.01145.x

Sedjo RA (1993) The carbon cycle and global forest ecosystem. Water Air Soil Pollut 70(1):295-307. https://doi.org/10.1007/BF01105003

Shao G, Shugart HH (1997) Notes: A compatible growth-density stand model derived from a distance-dependent individual tree model. Forest Sci 43(3): 443-446

Shao YN, Tian SY, Liu YK, Li YH, Sun ZH (2017) Effects of density control on soil respiration in Larix olgensis plantation. J Beijing Forestry Univ 39(6):51-59

Shrestha RK, Strahm BD, Sucre EB, Holub SM, Meehan N (2014) Fertilizer management, parent material, and stand age influence forest soil greenhouse gas fluxes. Soil Sci Soc Am J 78(6):2041-2053. https://doi.org/1 0.2136/sssaj2014.03.0118

Strong WL, Roi GHL (1983) Root-system morphology of common boreal forest trees in alberta, canada. Can J Res 13(6):1164-1173

Teskey, RO, Grier CC, Hinckley TM (1985) Relation between root system size and water inflow capacity of abies amabilis growing in a subalpine forest. Can J Forest Res 15(4):669-672.

Tian Q, He H, Cheng W, Bai Z, Wang Y, Zhang X (2016) Factors controlling soil organic carbon stability along a temperate forest altitudinal gradient. Sci Rep 6(1):18783. https://doi.org/10.1038/srep18783

Wander MM, Traina SJ, Stinner BR, Peters SE (1994) Organic and conventional management effects on biologically active soil organic matter pools. Soil Sci Soc Am J 58(4):1130-1139

Wei W, Weile C, Wang S (2010) Forest soil respiration and its heterotrophic and autotrophic components: global patterns and responses to temperature and precipitation. Soil Biol Biochem 42(8):1236-1244. https://doi.org/10.1016/j. soilbio.2010.04.013

Wic Baena C, Andrés-Abellán M, Lucas-Borja ME, Martínez-García E, García-Morote FA, Rubio E, López-Serrano FR (2013) Thinning and recovery effects on soil properties in two sites of a Mediterranean forest, in Cuenca Mountain (South-eastern of Spain). Forest Ecol Manage 308:223-230. https://doi.org/1 0.1016/j.foreco.2013.06.065

Wu T, Schoenau JJ, Li F, Qian P, Malhi SS, Shi Y (2003) Effect of tillage and rotation on organic carbon forms of chernozemic soils in Saskatchewan. J Plant Nutr Soil Sci 166(3):328-335. https://doi.org/10.1002/jpln.200390051

Wu X, Xu H, Tuo D, Wang C, Bojie F, Lv Y, Liu G (2020) Land use change and stand age regulate soil respiration by influencing soil substrate supply and microbial community. Geoderma 359:113991. https://doi.org/10.1016/j. geoderma.2019.113991

Xu M, Shang H (2016) Contribution of soil respiration to the global carbon equation. J Plant Physiol 203:16-28. https:/doi.org/10.1016/j.jplph.2016.08.007

Yang Y, Geng Y, Zhou H, Zhao G, Wang L (2017) Effects of gaps in the forest canopy on soil microbial communities and enzyme activity in a Chinese pine forest. Pedobiologia 61:51-60. https://doi.org/10.1016/j.pedobi.2017.03.001
You Y, Wang J, Huang X, Tang Z, Liu S, Sun OJ (2014) Relating microbial community structure to functioning in forest soil organic carbon transformation and turnover. Ecol Evol 4(5):633-647. https://doi.org/10.1002/ ece3.969

Yu K, Yao X, Deng Y, Lai Z, Lin L, Liu J (2019) Effects of stand age on soil respiration in Pinus massoniana plantations in the hilly red soil region of Southern China. Catena 178:313-321. https://doi.org/10.1016/j.catena.2019.03. 038

Zhang X, Guan D, Li W, Sun D, Jin C, Yuan F, Wang A, Jiabing W (2018) The effects of forest thinning on soil carbon stocks and dynamics: a metaanalysis. Forest Ecol Manage 429:36-43. https://doi.org/10.1016/j.foreco.2018. 06.027

Zhao B, Cao J, Geng Y, Zhao X, von Gadow K (2019) Inconsistent responses of soil respiration and its components to thinning intensity in a Pinus tabuliformis plantation in northern China. Agric Forest Meteorol 265:370-380. https://doi.org/10.1016/j.agrformet.2018.11.034

\section{Publisher's Note}

Springer Nature remains neutral with regard to jurisdictional claims in published maps and institutional affiliations.

\section{Submit your manuscript to a SpringerOpen ${ }^{\circ}$ journal and benefit from:}

- Convenient online submission

- Rigorous peer review

- Open access: articles freely available online

- High visibility within the field

- Retaining the copyright to your article

Submit your next manuscript at $\boldsymbol{\nabla}$ springeropen.com 